\title{
The news interview: Interviewing children
}

\section{ZEN LEGÊNE THOMSEN}

Previous studies on broadcast news interviews have primarily described the accountability interview with public figures such as politicians as interviewees. Drawing on the framework of conversation analysis this article investigates a different type of news interview interaction, namely that of journalist-child interaction within the morning news interview programme Go' morgen Danmark (Good morning Denmark). More specifically, the relevance of child identity in the news interview setting is discussed. It is argued that child identity is made relevant in the interviews not only by the explicitly ascription of categories such as "12-year-old", "9th grader" and "student council president", but also in several other ways. This can be observed when interviewers do not expect interviewees to be able to answer questions adequately, when interviewees are having difficulties doing so, and when interviewee identities that are not usually ascribed children, are oriented to as peculiar. Research literature on the news interview has characterized the interaction as a distinct type of institutional talk made up of questions and answers, and thus organised in accordance with a questionanswer format. This paper argues that the format is not constitutive for the genre under investigation. The participants in the data under study frequently depart from the question-answer format, and they only rarely treat these practises as deviant. 